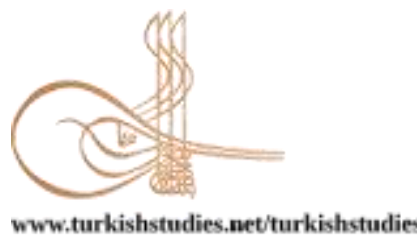

Turkish Studies

www.turkishstudies.net/turkishstudies

eISSN: $1308-2140$

BALAKAN

Sponsored by IBU

Research Article / Araștırma Makalesi

\title{
Üniversite Öğrencilerinin Toplumsal Cinsiyet Rollerine İlişkin Tutumlarının Bazı Demografik Değisskenler Açısından İncelenmesi
}

\author{
An Investigation of University Students' Attitudes Towards Gender Roles in Terms of Some \\ Demographic Variables
}

\author{
Nihan Yılmaz* - Birgül Çiçek ${ }^{* *}$
}

\begin{abstract}
This study was planned to examine university students' attitudes towards gender roles in terms of variables, such as gender, age, and grade, and it was conducted with 270 university students with different socio-demographic characteristics who continued their undergraduate education in Turkey. The research data were evaluated using SPSS.21 software. In the testing of the research hypotheses, the significance test of the difference between two groups and one-way analysis of variance (ANOVA) were performed. In cases when a statistically significant difference was detected as a result of ANOVA, Tukey's test was used for paired comparisons when variances were homogeneous, and Tamhane's T2 test was used when variances were not homogeneous. According to the results of the study, the mean GRAS score of the students included in the study was $\bar{X}=162.58 \pm 30.55$, and it was determined that their attitudes towards gender roles were egalitarian. Moreover, when students' attitudes towards gender roles were examined in terms of demographic and familial characteristics, there was no significant difference between students' gender, place of residence while studying at university, educational level of parents, total monthly income of the family, and GRAS and its subdimensions ( $p>0.05)$. However, it was found that students' attitudes towards gender roles differed statistically according to age, grade, perception level of the family income and family type, and that their attitudes towards "marriage gender roles" and "male gender roles" differed statistically according to the usual place of residence $(\mathrm{p}<0.05)$.
\end{abstract}

Structured Abstract: Purpose: It is of great importance to inform, raise consciousness and raise awareness of university students who are expected and desired to have a high level of positive perceptions of the egalitarian role and attitude based on the equality of women and men and who will also raise new generations by starting a family in the future. Therefore, the main purpose and importance of the study is to first determine

\footnotetext{
* Arş. Gör. Dr., Hacettepe Üniversitesi, İktisadi ve İdari Bilimler Fakültesi, Aile ve Tüketici Bilimleri Bölümü Res. Asst. Dr. Hacettepe University, Faculty of Economics and Administrative Sciences, Department of Family and Consumer Sciences

ORCID 0000-0002-2451-0852

nihangursoy@hacettepe.edu.tr

** Arş. Gör., Hacettepe Üniversitesi, İktisadi ve İdari Bilimler Fakültesi, Aile ve Tüketici Bilimleri Bölümü

Res. Asst. Hacettepe University, Faculty of Economics and Administrative Sciences, Department of Family and Consumer Sciences

ORCID 0000-0002-3985-6637

birgulaydin@hacettepe.edu.tr

Cite as/ Atıf: Yılmaz, N., \& Çiçek, B. (2021). Üniversite öğrencilerinin toplumsal cinsiyet rollerine ilişskin tutumlarının bazı demografik değişkenler açısından incelenmesi. Turkish Studies, 16(1), 437-452.
} https://dx.doi.org/10.7827/TurkishStudies.48114

Received/Geliş: 02 December/Aralık 2020

Accepted/Kabul: 20 Şubat/February 2021

Checked by plagiarism software

Published/Yayın: 25 Şubat/February 2021

CC BY-NC 4.0 
students' attitudes towards gender roles and to make recommendations to increase their current level of knowledge and awareness.

Method: This study was carried out with 270 university students with different socio-demographic characteristics who continue their undergraduate education in Turkey. The research data were obtained by the simple random sampling method through the online survey form prepared. The survey form consists of two sections. In the first section, there are descriptive questions such as gender, age, usual place of residence, educational status of their parents, including the demographic information of the students participating in the survey. In the second section, the "Gender Roles Attitude Scale-GRAS" developed by Zeyneloğlu (2008) was used to determine students' attitudes towards gender roles. Necessary permission was obtained for the use of the scale. The total C. alpha value of the scale is $\alpha=0.92$. In our study, the internal reliability coefficient of the scale was found to be $\alpha=0.96$. Before starting the study, necessary permission was obtained from Hacettepe University Ethics Commission (35853172-200 decision numbered). The research data were evaluated using SPSS.21 software. In the testing of the research hypotheses, the significance test of the difference between two groups and one-way analysis of variance (ANOVA) were performed. In cases when a statistically significant difference was detected as a result of ANOVA, Tukey's test was used for paired comparisons when variances were homogeneous, and Tamhane's T2 test was used when variances were not homogeneous.

Results and Discussion: The mean total scale score of the students included in the study was found to be $\bar{X}=162.58 \pm 30.55$. Zeyneloğlu (2008) stated that they had egalitarian attitudes towards gender roles as the mean total score obtained from the scale was 95 and above. Accordingly, it is observed that the attitudes of the students participating in the study towards gender roles are egalitarian.

In the study, it was revealed that university students' attitudes towards gender roles and their subdimensions do not differ according to students' gender. When the studies are examined, it is observed that the attitude towards gender roles is affected by gender and that female students in some studies and male students in others have a more egalitarian attitude towards gender roles. Since it is known that students' attitudes towards gender roles are affected by many socio-demographic characteristics as well as gender, it is thought that these differences between the studies originate from the sample included in the study.

The participants' attitudes towards gender roles and their sub-dimensions of "egalitarian gender roles," "female gender roles," "marriage gender roles", "traditional gender roles" anlamliliand "male gender roles" differ according to their grade. The mean "egalitarian gender roles" and "male gender roles" sub-dimension scores of the 3rd-grade students were found to be higher than those of the 4th-grade students. However, the 4th-grade students have a more traditional attitude towards the roles expected of women due to their gender, the roles that society traditionally expects from men and women, and the gender roles compared to the 1 st and 3rd-grade students. According to the findings obtained from our study and studies in the literature, it can be said that university education is insufficient in terms of providing students with a more egalitarian attitude towards gender roles. Although individuals form their own attitudes and behaviors in the socialization process by being influenced by the expectations, attitudes, and beliefs of the society they live in, it is thought that education is effective in the gradual change of these attitudes and beliefs acquired.

It was revealed that the attitudes of the university students included in the study towards "marriage gender roles" and "male gender roles" differ depending on the usual place of residence. It can be said that the students who stated that they had spent most of their lives in the village/town, in other words in rural areas, have a more traditional approach to the roles of men and women in the union of marriage established and that they have an attitude that bears the traces of patriarchal thought in the gender roles expected of men.

Students' attitudes towards gender roles and "female gender roles" and "traditional gender roles" differ according to students' family types. Students who have a nuclear family type have higher mean female gender roles and traditional gender roles sub-dimension scores from the GRAS and its sub-dimensions than those with an extended family. Similarly to the findings of the study Dinç and Çalışkan (2016), Başçı and Giray (2016), Seyitoğlu-Çelik, Güneş and Gökçe (2016) indicated that students from nuclear families exhibited a more egalitarian approach than other students. Unlike Ergin, Bekar and Acar-Aydemir (2019) stated that those with divorced parents had more egalitarian attitudes.

Conclusion and recommendations: Considering that universities are the basic institutions leading the development and transformation of societies, it is of great importance to examine university students' attitudes towards gender roles. By taking the results into account, intervention and training programs can be 
recommended to promote and improve the egalitarian attitude of university students towards gender roles. Furthermore, the awareness level of university students can be increased with seminars or conferences to be held to transform gender perception.

Keywords: Family and consumer science, sex, gender, gender roles, gender roles attitudes, university students.

Öz: $\mathrm{Bu}$ çalı̧̧ma, üniversite öğrencilerinin toplumsal cinsiyet rollerine ilişkin tutumlarının cinsiyet, yaş, öğrenim gördüğü sınıfı gibi değişkenler açısından incelenmesi amacıyla planlanmış, Türkiye'de lisans eğitimine devam eden farklı sosyo-demografik özelliklere sahip 270 üniversite öğrencisi ile yürütülmüștür. Araştırmanın verileri SPSS.21 programında değerlendirilmiştir. Araştırma hipotezlerinin testinde İki Grup Arasındaki Farkın Anlamlılık Testi (T testi) ve Tek Yönlü Varyans Analizi (ANOVA) testleri yapılmıştır. ANOVA sonucunda istatistiksel olarak anlamlı fark saptandığı durumlarda varyansların homojen olduğu durumlarda ikili karşılaştırmalar için Tukey Testi, varyansların homojen olmadığı durumlarda ise Tamhane's T2 Testi kullanılmıştır. Çalışmanın sonuçlarına göre; araştırma kapsamına alınan öğrencilerin Toplumsal Cinsiyet Rolleri Tutum Ölçeği (TCRTÖ) puan ortalaması $\bar{X}=162,58 \pm 30,55$ olup, toplumsal cinsiyet rollerine ilişkin tutumlarının eşitlikçi yönde olduğu belirlenmiş̧ir. Ayrıca öğrencilerin demografik ve ailesel özellikleri açısından toplumsal cinsiyet rollerine ilişkin tutumları incelendiğinde; öğrencilerin cinsiyeti, üniversite okurken yaşadığı yer, anne ve baba eğitim düzeyleri, ailenin toplam aylık geliri ile TCRT Ölçeği ve alt boyutları arasında anlamlı bir fark tespit edilmemiştir $(p>0.05)$. Bununla birlikte; öğrencilerin yaşı, sınıfı, aile gelirini algılama düzeyi ve aile tipine göre toplumsal cinsiyet rollerine ilişkin tutumlarının; yaşamının çoğunluğunu geçirdiği yere göre ise "evlilik cinsiyet rolleri” ve "erkek cinsiyet rolleri”ne ilişkin tutumlarının istatistiksel olarak fark gösterdiği belirlenmiştir $(p<0.05)$. Elde edilen bulgular toplumsal cinsiyet rollerine ilişkin tutum açısından güncel literatür çerçevesinde tartışılmış ve önerilerde bulunulmuştur.

Anahtar Kelimeler: Aile ve tüketici bilimleri, cinsiyet, toplumsal cinsiyet, toplumsal cinsiyet rollerine ilişkin tutum, üniversite öğrencileri.

\section{Giriş}

Toplumsal cinsiyet, son yıllarda yaygın olarak çeşitli bağlamlarda kullanılan bir terim haline gelmiş olması nedeniyle kapsamlı bir tartışmayı gerektirmekle birlikte başlıca biyolojik, cinsiyet bağlantılı davranışların kökenlerine ve süreğenliğine dayanmaktadır (Şafak, 2003: 803). "Cinsiyet" kadın ve erkeğin biyolojik farklılıklarından dolayı oluşan genetik, fizyolojik ve biyolojik özellikleri, "toplumsal cinsiyet" kavramı ise, insanların eril ve dişil olarak toplumun verdiği roller, görev ve sorumluluklar, toplumun bireyi nasıl gördüğü ile ilgili bir kavramdır (T.C. Başbakanlık Kadının Statüsü Genel Müdürlüğü, 2008). Dişsilik ve erkekliğin belirlendiği cinsiyet, insanların temel sınıflandırma kategorisidir. Cinsiyet kavramı doğa tarafından belirlenirken, toplumsal cinsiyet ise kültür tarafindan belirlenmektedir (Öngen ve Aytaç, 2018:2). Kadınlık ve erkeklik birbiriyle ilişkilidir, herbirinin tanımı diğerine bağlıdır. Hem erkekliğin hem kadınlığın bazı evrensel karakteristikleri olmasına rağmen, birinin sosyal yapısı diğerinin referans1 olmadan anlaşılamamaktadır (Kimmel, 1987: 12). Aslında doğa cinsiyet temelli ayrımı vermekte ve bunun okunması da her bir kültür tarafindan cümleler oluşturarak kadın ve erkek için simgesel alfabeyi üretmektedir. Bir anlamda her toplum, kadın ve erkeği farklı biçimde birleştiren kültürel yapılar ve toplumsal örgütlenmeler icat etmekte ve toplumları evrensel olarak oluşturan bir model meydana getirmektedir (Agacinski, 1998: 25; Ertürk, 1996:342). Kavramın sosyoloji literatürüne girmesi ise 1972 yılında Ann Oakley ile gerçekleşmiştir (Görgün-Baran, 2012: 410; Oakley, 1972:113). Toplumsal cinsiyet kavramı bir anlamda kadın ile erkek arasındaki farklılıkları ve eşitsizlikleri biyolojik yapı ile açıklamaya çalışan biyolojik temelli teorilere bir tepki olarak geliştirilmiştir (Illich, 1996:103).

Her toplumda kadın ve erkeği birbirinden ayıran bir dizi toplumsal ve kültürel değerler bulunmaktadır. Bu değerler bir kadın ve erkek modellerinin oluşmasını sağlamaktadır. Bireyin 
toplumla bütünleşme sürecini tanımlayan "toplumsallaşma" sonucu birey değer ve davranış kalıplarını benimseyerek yaşadığı toplumun bir parçası haline gelir. Bunun sonucunda bireyler cinsiyetlerini, içinde bulundukları toplumun o cinsiyete yüklediği anlam doğrultusunda inşa ederler (Uluocak ve diğerleri, 2014: 49). Bu süreç "cinsiyet tiplemesi” (sextyping) süreci olarak adlandırılır. Bireyler bu kategorileri oluştururken aile, okul vb. gibi birçok kaynaktan bilgi edinirler (Huston, 1985:9). Toplumsal cinsiyet kavramının temelinde, kadınlar ve erkekler için oluşturulmuş roller, öğrenilmiş davranış ve beklentiler bulunmaktadır (Akın ve Demirel, 2003:73; Staggenborg, 1998:3). Kadın ve erkek cinsleri arasında doğanın belirlediği farklılıklar dışında, iki cins arasında toplumsal düzlemde oluşturulmuş ve yerleşmiş farklılıklar bulunmakta ve iki cins tarafindan belirlenmiş ve benimsenmiş toplumsal rollerin var olduğu kabul edilmektedir. Toplumsal cinsiyet rolleri doğumla başlamaktadır ve sosyal yaptırımların üretimidir, etkileşimle yapılandırılmaktadır (Kammayer, 1987:31; West ve Zimmerman, 1987:127).

\section{Literatür Özeti}

Alanyazında, toplumsal cinsiyet rollerine ilişkin tutumu belirlemek amacıyla farklı sosyoekonomik özellikleri olan bireylere yönelik (üniversite öğrencileri, farklı meslek çalışanları vb.) yapılan çalışmalar güncelliğini korumaktadır. Öğrencilerin cinsiyet, yaş, medeni durum, sınıf, bölüm, fakülte, mezun olunan lise, aile geliri, geliri algılama düzeyi, aile tipi, kardeş sayıs1, ailelerinin yaşadığı yer, en uzun süre yaşanılan yer, üniversite okurken ikamet ettiğgi yer gibi bağımsız değişkenler ile toplumsal cinsiyet rollerine ilişkin tutumlar arasında ilişkilerin incelendiği görülmektedir. Özellikle, mesleğini yaparken toplumsal cinsiyet eşitliğini benimsemiş olmanın daha büyük önem arz ettiği öğrencilerle (tıp fakültesi, sağlık bilimleri fakültesi (hemşirelik, ebelik vb. bölümler), eğitim bilimleri fakültesi (farklı alanlarda öğretmen adayları), iletişim fakültesi, halkla ilişkiler bölümü öğrencileri) yapılmış çalışmalara daha çok rastlanılmıştır.

Alabaş, Akyüz ve Kamer'in (2019) çalışmasında kız öğrencilerin, ailesi ilde yaşayanların ve devlet yurdunda kalan öğrencilerin daha olumlu toplumsal cinsiyet algısına sahip olduğu sonucuna ulaşılmıştır. Daşl1 (2019) kız öğrencilerin erkek öğrencilerden daha yüksek oranda eşitlikçi toplumsal cinsiyet rol ve tutum içinde olduklarını bulmuştur. Bu çalışmanın aksine Çevik-Büyükşahin'in (2017) çalışmasında ise öğrencilerin cinsiyetine göre toplumsal cinsiyet rollerine ilişkin tutumlarının farklılaştığı, TCRT ölçeğinin tüm alt boyutlarında erkek öğrencilerin eşitlikçi rolleri benimsediği belirlenmiş̧ir. Halkla ilişkiler bölümünde okuyan öğrencilerle yürütülen Aydın ve Duğan'ın (2018) çalışmasında yaş, cinsiyet, sınıf, annenin ve babanın eğitim süresi toplumsal cinsiyet rollerine ilişkin tutumlarını anlamlı düzeyde yordadığı sonucuna varılmıştır. Başçı ve Giray (2016) tarafindan öğrencilerin sınıfına, fakültesine, üniversite öğrenimi devam ederken yaşadıkları yere, mezun oldukları lise türüne, aile tipine, anne-babanın eğitim düzeyine, annenin mesleğine ve ailenin gelir düzeyine göre TCRT ölçeği ortalamalarının farklılaştığı belirtilmiştir. Buna göre 6 . sınıf öğrencileri, iletişim fakültesinde okuyanlar, annesi lisansüstü babası lise mezunu olanlar, annesi emekliler, aile geliri 3501 TL'nin üzerinde olanların eşitlikçi tutuma sahip oldukları sonucuna varılmıştır. Dinç ve Çalışkan (2016) yaş, sınıf, mezun olunan lise türü, yaşadıkları yer, ekonomik düzeyleri, kardeş sayılarına göre öğrenciler arasında fark olmadığını; ancak kız öğrencilerin erkek öğrencilerden, çekirdek aileden gelen öğrencilerin diğer öğrencilerden daha eşitlikçi bir yaklaşım sergilediklerini belirtmiştir. Durgun-Köken ve Ulaş-Cambaz'ın (2019) ebelik ve hemşirelik öğrencilerinin demografik ve ailesel özelliklere göre incelediği çalışmasında kız öğrencilerin, yaşı 21 ve üzeri olanların, en uzun süre köyde ve ilçede yaşayanların, annesi ve babası ortaokul ve daha düşük eğitime sahip olanların daha eşitlikçi rol ve tutum içinde oldukları belirlenmiştir.

\section{Çalışmanın Önemi}

Alanyazında, üniversite öğrencilerinin demografik ve ailesel özellikler açısından toplumsal cinsiyet rollerine yönelik tutumlarını belirlemek amacıyla yapılan çalışmaların güncelliğini koruduğu; (Alabaş, Akyüz ve Kamer, 2019; Aydın ve Duğan, 2018; Başçı ve Giray, 2016; Çevik- 
Büyükşahin, 2017; Daşl1, 2019; Dinç ve Çalışkan, 2016; Durgun-Köken ve Ulaş-Cambaz, 2019; Ergin, Bekar ve Acar-Aydemir, 2019) ancak çalışmalardan elde edilen sonuçlar incelendiğinde; farklı demografik özelliklere sahip öğrencilerin halen geleneksel rol ve tutumun izlerini yansıttığı görülmektedir. Oysaki içinde yaşanılan toplumun cinsiyetlere özgü kadın ve erkeklerden beklediği toplumsal cinsiyete ilişkin roller; doğuştan değil, sonradan kazanılmış olarak ortaya çıkmaktadır. Buradan hareketle, kadın ve erkek eşitliğinin temel alındığı eşitlikçi rol ve tutuma ilişkin olumlu algılarının yüksek düzeyde olması beklenen ve istenen, aynı zamanda gelecekte aile kurarak yeni nesiller yetiştirecek gençlerin bu konuda bilgilendirilmesi, bilinçlendirilmesi ve farkındalık kazandırılması büyük önem arz etmektedir. Bu nedenle, öncelikli olarak öğrencilerin toplumsal cinsiyet rollerine ilişkin tutumlarının belirlenmesi, mevcut bilgi düzeylerinin ve farkındalıklarının artması için önerilerde bulunulması çalışmanın esas amacını ve önemini oluşturmaktadır.

\section{Yöntem}

\section{Veri Toplama Yöntem ve Araçları}

Bu çalışma, Türkiye'de lisans eğitimine devam eden farklı sosyo-demografik özelliklere sahip 270 üniversite öğrencisi ile yürütülmüştür. Araştırmanın verileri, hazırlanan çevrim içi anket formu aracılığıyla elde edilmiştir. Anket formu iki bölümden oluşmaktadır.

Birinci bölümde ankete katılan öğrencilerin demografik bilgilerini içeren cinsiyet, yaş, yaşamının çoğunluğunun geçtiği yer, anne ve babasının eğitim durumları gibi tanıtıcı sorular bulunmaktadır.

İkinci bölümde ise öğrencilerin toplumsal cinsiyet rollerine ilişkin tutumlarını belirlemek amaciyla Zeyneloğlu (2008) tarafından geliştirilen "Toplumsal Cinsiyet Rolleri Tutum ÖlçeğiTCRTÖ” kullanılmıştır. Ölçeğin kullanımı için gerekli izin alınmıştır. Ölçek 38 madde ve beş boyuttan (eşitlikçi cinsiyet rolü 8 madde, kadın cinsiyet rolü 8 madde, evlilikte cinsiyet rolü 8 madde, geleneksel cinsiyet rolü 8 madde ve erkek cinsiyet rolü 6 madde) oluşmaktadır. Ölçeğin toplam C. Alpha değeri $\alpha=0,92$ 'dir. Bu çalışmada ise ölçeğin iç güvenirlik katsayısı $\alpha=0,96$ olarak bulunmuştur. Alpar (2011:815) iç güvenirlik katsayısının .80 ile 1.00 arasında olmasını "yüksek derecede güvenilir" şeklinde açıklamaktadır. Buna göre; ölçeğin “yüksek derecede güvenilir" olduğu söylenebilir. 5'li likert tipinde hazırlanan ölçekte, en yüksek puan 190, en düşük puan ise 38'dir. Ölçekten alınan yüksek puan, bireylerin toplumsal cinsiyet rollerine ilişkin 'eşitlikçi tutuma sahip' olduğunu, düşük puan ise, bireylerin toplumsal cinsiyet rollerine ilişkin 'geleneksel tutuma sahip' olduğunu göstermektedir.

Araştırmanın verileri toplanmaya başlamadan önce Hacettepe Üniversitesi Etik Komisyonu'ndan (35853172-200 sayılı karar) gerekli izin alınmıştır. Hazırlanan anket formu "Google Forms" aracıllğıyla çevrim içi anket şeklinde oluşturulmuş, öğrencilere sosyal medya aracılığıyla ulaştırılmıştır. Çalışmaya katılan öğrencilerin öncelikle gönüllü katılım formunun okunması sağlanmıştır. Formda, araştırmanın amacından bahsedilmiş, araştırma formuyla elde edilen bilgilerin bilimsel amaçla kullanılacağı, bilimsel etik kuralları çerçevesinde gizlilik içinde değerlendirileceği ve başka bir amaçla kullanılmayacağı belirtilmiştir. Bu şartları kabul ettikleri takdirde anket formuna erişimleri sağlanmıştır.

\section{Verilerin Değerlendirilmesi ve Analizi}

Araştırmanın verileri SPSS.21 programında değerlendirilmiştir. Katılımcılara ilişkin demografik ve açıklayıcı bilgiler frekans, yüzde, ortalama ve standart sapma gibi tanımlayıcı istatistiklerle ifade edilmiştir. Araştırma hipotezlerinin testinde T Testi ve ANOVA testleri yapılmıştır. ANOVA sonucunda istatistiksel olarak anlamlı fark saptandığ 1 durumlarda varyansların homojen olduğu durumlarda ikili karşılaştırmalar için Tukey Testi, varyansların homojen olmadığı durumlarda ise Tamhane's T2 Testi kullanılmıştır. Analizlerden elde edilen sonuçlar \%95 güven aralığında ve $\alpha=0.05$ anlamlılık düzeyinde değerlendirilmiştir. 


\section{Bulgular}

\section{Katılımcıların Bireysel ve Ailesel Özelliklerine İlişkin Bilgiler}

Üniversite öğrencilerinin toplumsal cinsiyet rollerine ilișkin tutumlarının belirlenmesi amacıyla gerçekleştirilen bu çalışmada, katılımcıların \%86,3'ünün kadın, \%13,7'sinin erkek; \%67,8'inin 21-23 yaş aralığında; \%36,7'sinin 3. sınıf, \%34,8'inin ise 4. sınıf öğrencisi olduğu belirlenmiştir. Öğrencilerin yaşadıkları yer incelendiğinde; \%49,6'sının ailesiyle, \%36,3'ünün ise üniversite okurken yurtta yaşadığı saptanmıştır. Araştırmaya alınanlar arasında yaşamını büyükşsehirde geçirenlerin \%60,7 ile önde geldiği ve bunu \%17,0 ile yaşamını ilde geçirenlerin izlediği belirlenmiştir (Tablo 1).

Tablo 1: Çalışmaya Katılan Üniversite Öğrencilerinin Sosyo-Demografik Özelliklerine Göre Dağglımı

\begin{tabular}{cccc}
\hline Değişkenler & Gruplar & Sayı & \% \\
\hline \multirow{2}{*}{ Cinsiyet } & Kadın & 233 & 86,3 \\
& Erkek & 37 & 13,7 \\
& $18-20$ & 54 & 20,0 \\
\multirow{2}{*}{ Yaş } & $21-23$ & 183 & 67,8 \\
& 24 ve üzeri & 33 & 12,2 \\
\hline \multirow{2}{*}{ Sınıf } & 1 & 44 & 16,3 \\
& 2 & 33 & 12,2 \\
& 3 & 99 & 36,7 \\
& 4 & 94 & 34,8 \\
\hline \multirow{2}{*}{ Üniversite okurken yaşadığı } & Yurt & 98 & 36,3 \\
yer & Arkadaşlarımla evde & 24 & 8,9 \\
& Ailemle evde & 134 & 49,6 \\
& Diğer* & 14 & 5,2 \\
\hline \multirow{2}{*}{ Yaşamının çoğunluğunu } & Köy-kasaba & 18 & 6,7 \\
geçirdiği yer & İç̧e & 42 & 15,6 \\
& İl & 46 & 17,0 \\
Toplam & Büyükşehir & 164 & 60,7 \\
\hline
\end{tabular}

* Diğer: tek başına evde yaşayan, evli ya da akrabalarının yanında yaşayan öğrenciler

Öğrencilerin ailesel özelliklerine göre dağılımı incelendiğinde; annesinin eğitim düzeyi okuma yazma bilen veya ilkokul olanlar \%38,1 ile ilk sirada gelmekte; bunu lise mezunu $(\% 27,0)$ olanlar izlemektedir. Babasının eğitim düzeyi lisans ve üstü olanlar $\% 27,4$ iken; okuma yazma bilen veya ilkokul olanlar ise \%24,4 olarak belirlenmiş olup; lise düzeyinde eğitime sahip olanların oranı $\% 22,2$ 'dir. Ailenin toplam aylık gelirine bakıldığında; \%32,2'si 5000-5999 TL gelire sahipken; 6000 TL ve üzeri gelire sahip olanların oranı \%27,4'tür. Katılımcıların \%71,5'i gelirlerini “orta düzey” olarak belirtmiştir. Aile tipi “çekirdek” olanlar $(\% 83,0)$ ise büyük çoğunluktadır (Tablo 2). 
Tablo 2: Çalışmaya Katılan Üniversite Öğrencilerinin Ailesel Özelliklerine Göre Dağılımı

\begin{tabular}{|c|c|c|c|}
\hline Değişkenler & Gruplar & Sayı & $\%$ \\
\hline \multirow{5}{*}{ Annenin Eğitim Düzeyi } & $\begin{array}{l}\text { Okuma yazma } \\
\text { biliyor/Illkokul }\end{array}$ & 103 & 38,1 \\
\hline & Ortaokul & 47 & 17,4 \\
\hline & Lise & 73 & 27,0 \\
\hline & Ön lisans & 10 & 3,7 \\
\hline & Lisans ve üstü & 37 & 13,7 \\
\hline \multirow{5}{*}{ Babanın Eğitim Düzeyi } & $\begin{array}{l}\text { Okuma yazma } \\
\text { biliyor/Illkokul }\end{array}$ & 66 & 24 \\
\hline & Ortaokul & 57 & 21,1 \\
\hline & Lise & 60 & 22,2 \\
\hline & Ön lisans & 13 & 4,8 \\
\hline & Lisans ve üstü & 74 & 27,4 \\
\hline \multirow{6}{*}{$\begin{array}{c}\text { Ailenin Toplam Aylık } \\
\text { Geliri }\end{array}$} & 2324 TL ve daha az & 45 & 16,7 \\
\hline & 2325-2999 TL & 28 & 10,4 \\
\hline & 3000-3999 TL & 36 & 13,3 \\
\hline & 4000-4999 TL & 0 & 0,0 \\
\hline & 5000-5999 TL & 87 & 32,2 \\
\hline & 6000 TL ve üzeri & 74 & 27,4 \\
\hline \multirow{3}{*}{ Gelir Algılama Düzeyi } & Alt & 54 & 20,0 \\
\hline & Orta & 193 & 71,5 \\
\hline & Üst & 23 & 8,5 \\
\hline \multirow{2}{*}{ Aile Tipi } & Geniş aile & 46 & 17,0 \\
\hline & Çekirdek aile & 224 & 83,0 \\
\hline Toplam & & 270 & 100,0 \\
\hline
\end{tabular}

\section{Bulgular \\ Üniversite Öğrencilerinin Toplumsal Cinsiyet Rollerine Yönelik Tutumlarına İlişkin}

Üniversite öğrencilerinin TCRT ölçeğinden aldıkları toplam ve alt boyut puanlarına ait tanımlayıcı istatistikler yer aldığı Tablo 3'e göre; çalışma kapsamına alınan öğrencilerin toplam ölçek puan ortalamas $1 \overline{\mathrm{X}}=162,58 \pm 30,55$ 'tir. Ölçekten alınabilecek mininim puan 38, maksimum puan 190 olduğu düşünüldüğünde; araştırmaya katılan öğrencilerin toplumsal cinsiyet rollerine ilişkin tutumlarının eşitlikçi yönde olduğu görülmektedir. Alt boyutlara ilişkin ortalamalar incelendiğinde ise "eşitlikçi cinsiyet rolleri” ( $\overline{\mathrm{X}}=37,52)$, "kadın cinsiyet rolleri” ( $\overline{\mathrm{X}}=31,09)$, "evlilik cinsiyet rolleri” ( $\bar{X}=37,04)$, "geleneksel cinsiyet rolleri" $(\bar{X}=31,24)$ ve "erkek cinsiyet rolleri" $(\bar{X}=25,64)$ olarak bulunmuştur. Buna göre, öğrencilerin kadınların ve erkeklerin cinsiyetlerinden dolayı kendilerinden beklenen rol ve sorumluluklara, evlilikte kadın ve erkeklerin eşlik rol ve sorumluluklarına, geleneksel olarak toplumun kadın ve erkekten beklediği rol ve sorumluluklara daha eşitlikçi bir tutum içerisinde oldukları belirlenmiştir. 
Tablo 3: TCRT Ölçeği ve Alt Boyutlarına İlişsin Ortalama ve Standart Sapma Değerleri

\begin{tabular}{cccc}
\hline Alt Boyutlar ve Ölçek & Ort. & Std. Sapma & $\begin{array}{c}\text { Min. ve Max } \\
\text { puanlar }\end{array}$ \\
\hline Eşitlikçi cinsiyet rolleri & 37,57 & 5,26 & $(8-40)$ \\
\hline Kadın cinsiyet rolleri & 31,09 & 9,12 & $(8-40)$ \\
\hline Evlilik cinsiyet rolleri & 37,04 & 5,02 & $(8-40)$ \\
\hline Geleneksel cinsiyet rolleri & 31,24 & 9,49 & $(8-40)$ \\
\hline Erkek cinsiyet rolleri & 25,64 & 5,31 & $(6-30)$ \\
\hline TCRT Ölçeği & 162,58 & 30,55 & $(38-190)$ \\
\hline
\end{tabular}

Araştırma kapsamına alınan üniversite öğrencilerinin TCRT Ölçeği ve alt boyutlarının cinsiyete göre farklılaşma durumunu belirlemek için $T$ testi; yaşadığ 1 yer, anne ve baba eğitim düzeyleri, ailenin toplam aylık gelirine göre farklılaşma durumunu belirlemek için ise ANOVA yapılmıştır. Katılımcıların cinsiyet, üniversite okurken yaşadığı yer, anne ve baba eğitim düzeyleri, ailenin toplam aylık geliri ile TCRT Ölçeği ve alt boyutları arasında anlamlı bir fark tespit edilmemiştir $(p>0.05)$. Katılımcıların toplumsal cinsiyet rollerine ilişkin tutumları ile anlamlı ilişki içinde olmayan bağımsız değişkenlerin tabloları yapılmamış olup, elde edilen bulgular alanyazından çalışmalarla tartışılmıştır.

Üniversite öğrencilerinin TCRT Ölçeği ve alt boyutlarının yaşına göre göre farklılaşma durumunu belirlemek için ANOVA yapılmıştır. Test sonucunda, "eşitlikçi cinsiyet rolleri”, "kadın cinsiyet rolleri", "evlilik cinsiyet rolleri", "geleneksel cinsiyet rolleri", "erkek cinsiyet rolleri" alt boyutları ve "TCRT Ölçeği" ile yaş grupları arasında istatistiksel olarak anlamlı derecede bir farklılık bulunmaktadır $(p<0,05)$. Yaş gruplarına göre anlamlı farklılıkların hangi gruplardan kaynaklandığının belirlenmesinde Tamhane's T2 testinden yararlanılmıştır (Tablo 4).

Buna göre; $18-20$ yaş aralığında olan öğrencilerin tüm alt boyutlarda (eşitlikçi cinsiyet rolleri için $\bar{X}=39,44$; kadın cinsiyet rolleri için $\bar{X}=35,54$; evlilik cinsiyet rolleri için $\bar{X}=38,83$; geleneksel cinsiyet rolleri için $\bar{X}=34,80$ ve erkek cinsiyet rolleri için $\bar{X}=27,35)$ ve TCRT ölçeği $(\bar{X}=175,96)$ ortalamaları diğer yaş gruplarına göre daha yüksek olarak belirlenmiştir. Ayrıca 21-23 yaş grubundaki öğrencilerin "kadın cinsiyet rolleri" $(\bar{X}=30,85)$ ve "geleneksel cinsiyet rolleri" $(\bar{X}=31,26)$ alt boyut ortalamaları, 24+ yaş grubunda olan öğrencilerden $(\bar{X}=25,15 ; \bar{X}=25,30)$ daha yüksektir (Tablo 4).

Tablo 4: Çalışmaya Katılan Üniversite Öğrencilerinin Yaşına Göre TCRT Ölçeği ve Alt Boyutları Ortalamalarına İlişkin ANOVA Sonuçları

\begin{tabular}{|c|c|c|c|c|c|c|c|}
\hline Alt Boyutlar & Yaş & $\mathbf{n}$ & $\overline{\bar{X}}$ & sd & $F$ & $p$ & Fark \\
\hline \multirow{3}{*}{$\begin{array}{l}\text { Eşitlikçi cinsiyet } \\
\text { rolleri }\end{array}$} & $18-20$ & 54 & 39,44 & 2,345 & \multirow{3}{*}{7,562} & \multirow{3}{*}{,001* } & \multirow{3}{*}{$1-2,3$} \\
\hline & $21-23$ & 183 & 37,47 & 5,310 & & & \\
\hline & $24+$ & 33 & 35,06 & 7,132 & & & \\
\hline \multirow{3}{*}{$\begin{array}{l}\text { Kadın cinsiyet } \\
\text { rolleri }\end{array}$} & $18-20$ & 54 & 35,54 & 4,133 & \multirow{3}{*}{14,846} & \multirow{3}{*}{, $000 *$} & \multirow{3}{*}{$\begin{array}{r}1-2,3 \\
2-3\end{array}$} \\
\hline & $21-23$ & 183 & 30,85 & 9,127 & & & \\
\hline & $24+$ & 33 & 25,15 & 11,317 & & & \\
\hline \multirow{3}{*}{$\begin{array}{l}\text { Evlilik cinsiyet } \\
\text { rolleri }\end{array}$} & $18-20$ & 54 & 38,83 & 2,329 & \multirow{3}{*}{5,757} & \multirow{3}{*}{,004* } & \multirow{3}{*}{$1-2,3$} \\
\hline & $21-23$ & 183 & 36,83 & 5,248 & & & \\
\hline & $24+$ & 33 & 35,30 & 6,182 & & & \\
\hline \multirow{3}{*}{$\begin{array}{l}\text { Geleneksel } \\
\text { cinsiyet rolleri }\end{array}$} & $18-20$ & 54 & 34,80 & 5,625 & \multirow{3}{*}{11,000} & \multirow{3}{*}{, $000 *$} & \multirow{3}{*}{$\begin{array}{c}1-2,3 \\
2-3\end{array}$} \\
\hline & $21-23$ & 183 & 31,26 & 9,484 & & & \\
\hline & $24+$ & 33 & 25,30 & 11,671 & & & \\
\hline \multirow{3}{*}{$\begin{array}{l}\text { Erkek cinsiyet } \\
\text { rolleri }\end{array}$} & $18-20$ & 54 & 27,35 & 3,035 & \multirow{3}{*}{5,453} & \multirow{3}{*}{, $005^{*}$} & \multirow{3}{*}{$1-2,3$} \\
\hline & $21-23$ & 183 & 25,50 & 5,493 & & & \\
\hline & $24+$ & 33 & 23,61 & 6,442 & & & \\
\hline
\end{tabular}




\begin{tabular}{c|c|c|c|c|c|c|c}
\hline \multirow{2}{*}{ TCRT Ölçeği } & $18-20$ & 54 & 175,96 & 13,702 & \multirow{2}{*}{11,949} & \multirow{2}{*}{, $000 *$} & $1-2,3$ \\
& $21-23$ & 183 & 161,91 & 30,715 & 11,949 & & \\
\hline
\end{tabular}

$* p<0,05$

Tablo 5 incelendiğinde "eşitlikçi cinsiyet rolleri”, "kadın cinsiyet rolleri”, "evlilik cinsiyet rolleri", "geleneksel cinsiyet rolleri", "erkek cinsiyet rolleri" alt boyutları ve "TCRT Ölçeği" ile öğrencilerin okudukları sınıf arasında istatistiksel olarak anlamlı derecede bir farklılık bulunmaktadır $(p<0,05)$. Öğrencilerin okudukları sinıflara göre anlamlı farklılıkların hangi gruplardan kaynaklandığının belirlenmesinde Tamhane's T2 testinden yararlanılmıştır.

3. sınıf öğrencilerinin "eşitlikçi cinsiyet rolleri" $(\bar{X}=38,60)$, ve "erkek cinsiyet rolleri" $(\bar{X}=26,72)$ alt boyut ortalamaları 4. sinıfta okuyan öğrencilere $(\bar{X}=36,31 ; \bar{X}=24,30)$ göre daha yüksek bulunmuştur. Bununla birlikte; "kadın cinsiyet rolleri" $(\bar{X}=27,50)$ ile "geleneksel cinsiyet rolleri" $(\bar{X}=27,98)$ alt boyutları ve "TCRT ölçeği”"nde $(\bar{X}=152,14)$ ise 4 . sınıf öğrencilerinin ortalamaları, 1 . sınıf ve 3. sınıf öğrencilerinden daha düşüktür (Tablo 5).

Tablo 5: Çalışmaya Katılan Üniversite Öğrencilerinin Sınıfına Göre TCRT Ölçeği ve Alt Boyutları Ortalamalarına İlişkin ANOVA Sonuçları

\begin{tabular}{|c|c|c|c|c|c|c|c|}
\hline Alt Boyutlar & Sinıf & $\mathbf{n}$ & $\overline{\bar{X}}$ & sd & $F$ & $p$ & Fark \\
\hline \multirow{4}{*}{$\begin{array}{l}\text { Eşitlikçi cinsiyet } \\
\text { rolleri }\end{array}$} & 1 & 44 & 38,25 & 5,50 & \multirow{4}{*}{3,451} & \multirow{4}{*}{, $017 *$} & \multirow{4}{*}{$3-4$} \\
\hline & 2 & 33 & 37,18 & 4,99 & & & \\
\hline & 3 & 99 & 38,60 & 4,44 & & & \\
\hline & 4 & 94 & 36,31 & 5,80 & & & \\
\hline \multirow{4}{*}{$\begin{array}{l}\text { Kadın cinsiyet } \\
\text { rolleri }\end{array}$} & 1 & 44 & 33,61 & 7,12 & \multirow{4}{*}{8,866} & \multirow{4}{*}{, $000^{*}$} & \multirow{4}{*}{$4-1,3$} \\
\hline & 2 & 33 & 30,91 & 10,03 & & & \\
\hline & 3 & 99 & 33,43 & 7,14 & & & \\
\hline & 4 & 94 & 27,50 & 10,35 & & & \\
\hline \multirow{4}{*}{$\begin{array}{l}\text { Geleneksel cinsiyet } \\
\text { rolleri }\end{array}$} & 1 & 44 & 32,50 & 7,72 & \multirow{4}{*}{6,631} & \multirow{4}{*}{, $000^{*}$} & \multirow{4}{*}{$4-1,3$} \\
\hline & 2 & 33 & 31,36 & 9,24 & & & \\
\hline & 3 & 99 & 33,74 & 7,91 & & & \\
\hline & 4 & 94 & 27,98 & 10,93 & & & \\
\hline \multirow{4}{*}{$\begin{array}{l}\text { Erkek cinsiyet } \\
\text { rolleri }\end{array}$} & 1 & 44 & 26,16 & 4,82 & \multirow{4}{*}{3,597} & \multirow{4}{*}{,014* } & \multirow{4}{*}{$3-4$} \\
\hline & 2 & 33 & 25,52 & 4,66 & & & \\
\hline & 3 & 99 & 26,72 & 4,38 & & & \\
\hline & 4 & 94 & 24,30 & 6,33 & & & \\
\hline \multirow{4}{*}{ TCRT Ölçeği } & 1 & 44 & 167,98 & 27,40 & \multirow{4}{*}{6,461} & \multirow{4}{*}{, $000 *$} & \multirow{4}{*}{$4-1,3$} \\
\hline & 2 & 33 & 162,73 & 28,72 & & & \\
\hline & 3 & 99 & 170,05 & 24,95 & & & \\
\hline & 4 & 94 & 152,14 & 35,06 & & & \\
\hline
\end{tabular}

$* p<0,05$

Tablo 6'ya göre tüm alt boyutlar ile TCRT ölçeğinde geliri algılama düzeyleri istatistiksel olarak anlamlıdır $(p<0,05)$. Öğrencilerin geliri algılama düzeylerine göre anlamlı farklılıkların hangi gruplardan kaynaklandığının belirlenmesinde Tamhane's T2 testinden yararlanılmıştır (Tablo 6).

Testin sonuçlarına göre; çalışmaya katılan üniversite öğrencilerinden "eşitlikçi cinsiyet rolleri” ( $\bar{X}=33,65)$, "kadın cinsiyet rolleri” $(\bar{X}=24,39)$, "evlilik cinsiyet rolleri” $(\bar{X}=32,61)$, "geleneksel cinsiyet rolleri” ( $\bar{X}=22,70)$ ve "erkek cinsiyet rolleri" $(\bar{X}=21,91)$ alt boyutları ile "TCRT ölçeği”"nde $(\bar{X}=135,26)$ gelir algıs1 "yüksek" olan öğrencilerin ortalamaları, ailesinin gelirini düşük ve orta düzeyde algilayan öğrencilere göre daha düşüktür (Tablo 6). 
Tablo 6: Çalışmaya Katılan Üniversite Öğrencilerinin Geliri Algılama Düzeyine Göre TCRT Ölçeği ve Alt Boyutları Ortalamalarına İlişkin ANOVA Sonuçları

\begin{tabular}{|c|c|c|c|c|c|c|c|}
\hline Alt Boyutlar & $\begin{array}{c}\text { Geliri Algılama } \\
\text { Düzeyi }\end{array}$ & $\mathbf{n}$ & $\bar{X}$ & sd & $F$ & $p$ & Fark \\
\hline $\begin{array}{l}\text { Eşitlikçi cinsiyet } \\
\text { rolleri }\end{array}$ & $\begin{array}{c}\text { Düssük } \\
\text { Orta } \\
\text { Yüksek }\end{array}$ & $\begin{array}{c}54 \\
193 \\
23\end{array}$ & $\begin{array}{l}37,41 \\
38,08 \\
33,65\end{array}$ & $\begin{array}{c}5,89 \\
4,27 \\
8,79\end{array}$ & 7,679 &, $001^{*}$ & $3-1,2$ \\
\hline $\begin{array}{l}\text { Kadın cinsiyet } \\
\text { rolleri }\end{array}$ & $\begin{array}{c}\text { Düssük } \\
\text { Orta } \\
\text { Yüksek }\end{array}$ & $\begin{array}{c}54 \\
193 \\
23\end{array}$ & $\begin{array}{l}31,02 \\
31,91 \\
24,39\end{array}$ & $\begin{array}{c}8,625 \\
8,473 \\
12,648\end{array}$ & 7,295 &, $001 *$ & $3-1,2$ \\
\hline $\begin{array}{l}\text { Evlilik cinsiyet } \\
\text { rolleri }\end{array}$ & $\begin{array}{l}\text { Düssük } \\
\text { Orta } \\
\text { Yüksek }\end{array}$ & $\begin{array}{c}54 \\
193 \\
23\end{array}$ & $\begin{array}{l}36,59 \\
37,70 \\
32,61\end{array}$ & $\begin{array}{l}5,970 \\
3,939 \\
7,947\end{array}$ & 11,657 &, $000 *$ & $3-1,2$ \\
\hline $\begin{array}{l}\text { Geleneksel cinsiyet } \\
\text { rolleri }\end{array}$ & $\begin{array}{c}\text { Düşük } \\
\text { Orta } \\
\text { Yüksek }\end{array}$ & $\begin{array}{c}54 \\
193 \\
23\end{array}$ & $\begin{array}{l}32,48 \\
31,91 \\
22,70\end{array}$ & $\begin{array}{c}8,323 \\
8,905 \\
12,625\end{array}$ & 11,021 &, $000 *$ & $3-1,2$ \\
\hline $\begin{array}{l}\text { Erkek cinsiyet } \\
\text { rolleri }\end{array}$ & $\begin{array}{l}\text { Düşük } \\
\text { Orta } \\
\text { Yüksek }\end{array}$ & $\begin{array}{c}54 \\
193 \\
23\end{array}$ & $\begin{array}{l}25,59 \\
26,09 \\
21,91\end{array}$ & $\begin{array}{l}5,970 \\
4,583 \\
7,763\end{array}$ & 6,618 &, $002 *$ & $3-1,2$ \\
\hline TCRT Ölçeği & $\begin{array}{l}\text { Düşük } \\
\text { Orta } \\
\text { Yüksek }\end{array}$ & $\begin{array}{c}54 \\
193 \\
23\end{array}$ & $\begin{array}{l}163,09 \\
165,69 \\
135,26\end{array}$ & $\begin{array}{l}30,273 \\
26,707 \\
46,010\end{array}$ & 10,959 &, $000 *$ & $3-1,2$ \\
\hline
\end{tabular}

${ }^{*} p<0,05$

"Evlilik cinsiyet rolleri” ve "erkek cinsiyet rolleri” alt boyutları ile yaşamın çoğunluğunun geçirildiği yer arasında istatistiksel olarak anlamlı derecede bir farklılık bulunmaktadır $(p<0,05)$. Öğrencilerin yaşamının çoğunluğunu geçirdiği yere göre anlamlı farklılıkların hangi gruplardan kaynaklandığının belirlenmesinde Tamhane's T2 ve Tukey testinden yararlanılmıştır (Tablo 7).

Yapılan ileri testlere göre, köy/kasabada yaşayanların "evlilik cinsiyet rolleri” alt boyut $(\bar{X}=33,61)$ ortalaması, ilçe, il ve büyükşehirde yaşadığını belirten öğrencilere göre; "erkek cinsiyet rolleri" alt boyutu ( $\bar{X}=33,61)$ ortalaması ise, il ve büyükşehirde yaşamının çoğunluğunu geçiren öğrencilere göre daha düşük olarak bulunmuştur (Tablo 7).

Tablo 7: Çalışmaya Katılan Üniversite Öğrencilerinin Yaşamının Çoğunluğunu Geçirdiği Yere Göre TCRT Ölçeği ve Alt Boyutları Ortalamalarına İlişkin ANOVA Sonuçları

\begin{tabular}{|c|c|c|c|c|c|c|c|}
\hline Alt Boyutlar & $\begin{array}{c}\text { Yaşamının çoğunluğunu } \\
\text { geçirdiği yer }\end{array}$ & n & $\bar{X}$ & sd & $F$ & $p$ & Fark \\
\hline $\begin{array}{l}\text { Evlilik cinsiyet } \\
\text { rolleri }\end{array}$ & $\begin{array}{l}\text { Köy/kasaba } \\
\text { İlçe } \\
\text { Il } \\
\text { Büyükşehir } \\
\end{array}$ & $\begin{array}{c}18 \\
42 \\
46 \\
164 \\
\end{array}$ & $\begin{array}{l}33,61 \\
37,50 \\
37,54 \\
37,16 \\
\end{array}$ & $\begin{array}{l}7,69 \\
3,00 \\
4,04 \\
5,22 \\
\end{array}$ & 3,168 &, $025 *$ & $1-2,3,4$ \\
\hline $\begin{array}{l}\text { Erkek cinsiyet } \\
\text { rolleri }\end{array}$ & $\begin{array}{c}\text { Köy/kasaba } \\
\text { İlçe } \\
\text { İl } \\
\text { Büyükşsehir }\end{array}$ & $\begin{array}{c}18 \\
42 \\
46 \\
164\end{array}$ & $\begin{array}{l}21,94 \\
25,29 \\
25,91 \\
26,05\end{array}$ & $\begin{array}{l}7,06 \\
4,35 \\
4,71 \\
5,36\end{array}$ & 3,423 & ,018* & $1-3,4$ \\
\hline
\end{tabular}

$* p<0,05$ 
Tablo 8'e göre" kadın cinsiyet rolleri”, "geleneksel cinsiyet rolleri” alt boyutları ve "TCRT Ölçeği”" ile katılımcıların aile tipi arasında anlamlı bir farklılık saptanmıştır ( $p<0,05)$.

Çekirdek ailede yaşadığını belirten öğrencilerin "Kadın cinsiyet rolleri" $(\bar{X}=31,70)$, "geleneksel cinsiyet rolleri" $(\bar{X}=31,76)$ alt boyutlarında ve "TCRT ölçeği”nde $(\bar{X}=164,49)$ ortalamaları, geniş ailede yaşayan öğrencilere göre daha yüksektir (Tablo 8).

Tablo 8: Çalışmaya Katılan Üniversite Öğrencilerinin Aile Tipine Göre TCRT Ölçeği ve Alt Boyutları Ortalamalarına İlişkin T testi Sonuçları

\begin{tabular}{|c|c|c|c|c|c|c|}
\hline Alt Boyutlar & Aile Tipi & $\mathbf{n}$ & $\overline{\mathrm{X}}$ & sd & $t$ & $p$ \\
\hline \multirow{2}{*}{$\begin{array}{l}\text { Kadın cinsiyet } \\
\text { rolleri }\end{array}$} & Geniş & 46 & 28,13 & 10,193 & \multirow[b]{2}{*}{-2.436} & \multirow{2}{*}{, $016^{*}$} \\
\hline & Çekirdek & 224 & 31,70 & 8,794 & & \\
\hline \multirow{2}{*}{$\begin{array}{l}\text { Geleneksel cinsiyet } \\
\text { rolleri }\end{array}$} & Geniş & 46 & 28,72 & 10,026 & \multirow[b]{2}{*}{-1.896} & \multirow{2}{*}{, $048 *$} \\
\hline & Çekirdek & 224 & 31,76 & 9,322 & & \\
\hline \multirow[b]{2}{*}{ TCRT Ölçeği } & Geniş & 46 & 153,30 & 35,624 & & \multirow[b]{2}{*}{, $023 *$} \\
\hline & Çekirdek & 224 & 164,49 & 29,132 & -2.278 & \\
\hline
\end{tabular}

$* p<0,05$

\section{Tartıșma}

Türkiye'de lisans eğitimine devam eden farklı sosyo-demografik özelliklere sahip 270 üniversite öğrencisi ile yürütülen bu çalışmada, katılımcılar arasında kadınlar (\%86,3), 21-23 yaş aralığında olanlar $(\% 67,8), 3$. sınıfta okuyanlar $(\% 36,7)$, üniversite eğitimi alırken ailesiyle birlikte yaşayanlar $(\% 49,6)$ ve yaşamının büyük çoğunluğunu büyükşehirde geçirenler $(\% 60,7)$ ilk sırada gelmektedir. Diğer yandan çalışmaya katılan üniversite öğrencileri ailesel özellikler açısından incelendiğinde; annesinin okuma yazma bilen veya ilkokulmezunu $(\% 38,1)$, babasının lisans ve lisans üstü $(\% 27,4)$ eğitim düzeyine sahip olan öğrenciler, 5000-5999 TL ailesinin toplam aylık geliri olanlar $(\% 32,2)$, aile gelirlerini "orta düzey" olarak algilayanlar $(\% 71,5)$ ve çekirdek ailede yaşayanlar $(\% 83,0)$ ilk sırada yer almaktadır.

Çalışma kapsamına alınan öğrencilerin toplam ölçek puan ortalaması $\bar{X}=162,58 \pm 30,55$ olarak bulunmuştur. Buna göre araştırmaya katılan öğrencilerin toplumsal cinsiyet rollerine ilişkin tutumlarının eşitlikçi yönde olduğu görülmektedir. Durgun-Köken ve Ulaş-Cambaz'ın (2019) ebelik ve hemşirelik bölümünde okuyan 801 öğrenci üzerinde gerçekleştirdiği araştırmasında ise hemşirelik öğrencilerinin $(\bar{X}=105.86 \pm 20.91)$ ve ebelik öğrencilerinin $(\bar{X}=108.69 \pm 11.52)$ eşitlikçi bir tutum içerisinde oldukları sonucuna varılmıştır. Seyitoğlu-Çelik, Güneş ve Gökçe'nin (2016) İnönü Üniversitesi Tıp Fakültesi'nde 684 öğrenci ile yürütülen ( $\bar{X}=139)$, Önder, Yalçın ve Göktaş (2013), ile Alan-Dikmen ve Marakoğlu'nun (2019) çalışmalarında da öğrencilerin eşitlikçi tutum sergilediği belirlenmiştir.

Araştırma kapsamına alınan üniversite öğrencilerinin toplumsal cinsiyet rollerine ve alt boyutlarına ilişkin tutumlarının öğrencilerin cinsiyetine göre farklılaşmadığ Alanyazın incelendiğinde cinsiyete ilişkin farklı bulguların elde edildiği görülmektedir. Kız öğrencilerin, erkek öğrencilere oranla toplumsal cinsiyet rollerine ilişkin daha eşitlikçi tutuma sahip olduklarını belirten çok sayıda çalışmaya rastlanılmıştır (Alabaş, Akyüz ve Kamer, 2019; Daşlı, 2019; Dinç ve Çalışkan, 2016; Direk ve Irmak, 2017; Ergin, Bekar ve Acar-Aydemir, 2019; DurgunKöken ve Ulaş-Cambaz,2019; Seyitoğlu-Çelik, Güneş ve Gökçe, 2016; Alan-Dikmen ve Marakoğlu,2019; Yazıc1, 2016) Aydın ve Duğan'ın (2018) araştırmasında da cinsiyetin toplumsal cinsiyet rollerine ilişkin tutumlarını anlamlı düzeyde yordadı ğı, kız öğrencilerin erkeklere göre daha eşitlikçi tutum sergilediği belirtilmiştir. Yapılan bu çalışmalarda erkek öğrencilerin daha geleneksel 
tutum içerisinde oldukları söylenebilir. Fakat bu bulguların aksine erkeklerin kız öğrencilere göre daha eşitlikçi bir tutum içerisinde olduğu çalışmalara da rastlanmıştır. Çevik-Büyükşahin'in (2017) Adıyaman Üniversitesi'nde okuyan 458 öğrencinin araştırma kapsamına alındığ çalışmasında, öğrencilerin cinsiyetine göre toplumsal cinsiyet rollerine ilişkin tutumlarının farklılaştığ 1 , TCRT ölçeği ve tüm alt boyutlarında erkek öğrencilerin eşitlikçi rolleri benimsediği; Önder, Yalçın ve Göktaş'ın (2013) çalışmasında da erkek öğrencilerin daha eşitlikçi tutum gösterdiği belirlenmiştir.

Çalışmaya katılan üniversite öğrencilerinin toplumsal cinsiyet rollerine ve alt boyutlarına ilişkin tutumlarının öğrencilerin anne ve baba eğitim düzeylerine göre farklılaşmadığı belirlenmiştir. $\mathrm{Bu}$ bulguya paralel olarak; Dinç ve Çalışkan da (2016) anne-babanın eğitim durumuna göre öğrenciler arasında fark olmadığını belirtmiştir. Anne babanın eğitim düzeyinin öğrencilerin toplumsal cinsiyet rollerine ilişkin tutum üzerinde etkili olduğunu belirten çalışmalara da rastlanmakla birlikte; eğitim düzeyi ile tutum arasında pozitif bir ilişkinin varlığından da söz edilememektedir. Aydın ve Duğan'ın (2018) çalışmasında annenin ve babanın eğitim süresi toplumsal cinsiyet rollerine ilişkin tutumlarını etkilediği sonucuna varılmıştır. Başçı ve Giray (2016) anne-babanın eğitim düzeyine göre TCRTÖ ortalamalarının farklılaştığı; annesi lisansüstü, babası lise mezunu olan öğrencilerin toplumsal cinsiyet rollerine ilişkin eşitlikçi tutuma sahip oldukları sonucuna varmıştır. Seyitoğlu-Çelik, Güneş ve Gökçe (2016) ile Yazıcı (2016) tarafından yapılan çalışmalarda ise anne eğitim düzeyi yüksek olan öğrencilerin daha eşitlikçi tutum gösterdiği belirtilmiştir. Durgun-Köken ve Ulaş-Cambaz (2019) ise çalışmasında annesi ve babası ortaokul ve daha düşük eğitime sahip olanların daha eşitlikçi rol ve tutum içinde olduklarınıbelirlemiştir.

Üniversite öğrencilerinin toplumsal cinsiyet rollerine ve alt boyutlarına ilişkin tutumlarının öğrencilerin üniversite okurken yaşadığ 1 yere göre farklılaşmadığı belirlenmiştir. Yurtta, arkadaşlarıyla evde, ailesiyle evde ve diğer* yerlerde kaldığını belirten öğrencilerin toplumsal cinsiyet rollerine ilişkin benzer tutum içerisinde oldukları söylenebilir. Ancak, Başçı ve Giray (2016) öğrencilerin üniversite öğrenimi devam ederken yaşadıkları yere göre TCRTÖ ortalamalarının farklılaştığını belirtirken; Alabaş, Akyüz ve Kamer (2019) devlet yurdunda kalan öğrencilerin daha olumlu toplumsal cinsiyet algısına sahip olduğu sonucuna ulaşmıştır.

Araştırma kapsamına alınan üniversite öğrencilerinin toplumsal cinsiyet rollerine ve alt boyutlarına ilişkin tutumlarının öğrencilerin ailenin toplam aylık gelirine göre farklılaşmadığı belirlenmiştir. Öğrencilerin ailesinin toplam aylık gelir düzeyi ne olursa olsun toplumsal cinsiyet rollerine ilişkin tutumlarının aynı olduğu görülmektedir. Benzer şekilde, Dinç ve Çalışkan da (2016) ekonomik düzeylerine göre öğrenciler arasında fark olmadığını ifade etmiştir. Ancak, ailenin gelir düzeyinin tutum üzerinde etkisinin olduğunu belirten çalışmalara da rastlanmıştır. Nitekim Başçı ve Giray (2016) ailenin gelir düzeyine TCRTÖ ortalamalarının farklılaştığı belirterek; aile gelirinin 3501 TL'nin üzerinde olan öğrencilerin toplumsal cinsiyet rollerine ilişkin eşitlikçi tutuma sahip oldukları sonucuna varmıştır.

Katılımcıların toplumsal cinsiyet rollerine ilişkin tutum ile aile gelirini algılama düzeyleri arasında fark olup olmadığı incelenmiştir. Elde edilen bulgulara göre; gelir algısı "yüksek" olan öğrencilerin toplumsal cinsiyet rollerine ilişkin tutum ve eşitlikçi cinsiyet rolleri, kadın cinsiyet rolleri, evlilik cinsiyet rolleri, geleneksel cinsiyet rolleri ve erkek cinsiyet rolleri alt boyutlarının ortalamaları, ailesinin gelirini düşük ve orta düzeyde algılayan öğrencilere göre daha düşük olduğubelirlenmiştir. Bu şaşırtıcı bir bulgu olarak karşımıza çıkmaktadır. Gelir algısının yüksek olduğu öğrencilerin toplumsal cinsiyet rollerine ilişkin daha geleneksel bir tutum içerisinde olduğu söylenebilir. Diğer bir deyişle düşük ve orta düzeyde gelir algısı olan öğrencilerin daha eşitlikçi tutuma sahip oldukları belirlenmiştir. $\mathrm{Bu}$ durumun nedenlerinin belirlenmesi amaciyla ileri çalışmaların planlanması önerilebilir. Elde edilen bulgunun aksine Önder, Yalçın ve Göktaş (2013) öğrencilerin gelir algısı ile toplumsal cinsiyet rollerine ilişkin tutum arasında herhangi bir farka rastlanmamıştır. 
Araştrımada 18-20 yaş aralığında olan öğrencilerin toplumsal cinsiyet rollerine ilişkin tutum ve tüm alt boyutların ortalamaları diğer yaş gruplarına göre daha yüksek bulunmuştur. Bu sonuca göre, yaşı küçük olan öğrencilerin daha eşitlikçi bir tutum içinde olduğu söylenebilir. Ayrıca 21-23 yaş grubundaki öğrencilerin "kadın cinsiyet rolleri" ve "geleneksel cinsiyet rolleri" alt boyut ortalamaları, 24+ yaş grubunda olan öğrencilerden daha yüksek olduğu çalışmanın diğer bulgularındandır. Buna göre, 21-23 yaş grubunda olan öğrencilerin kadınların cinsiyetlerinden dolayı kendilerinden beklenen rollere ve geleneksel olarak toplumun kadın ve erkekten beklediği rollere ilişkin 24 yaş ve üzerindeki öğrencilere göre daha eşitlikçi bir tutuma sahip olduğu görülmektedir. Alanyazında öğrencilerin yaşı ile toplumsal cinsiyet rollerine ilişkin tutum arasında ilişki olduğunu, bu ilişkinin farklı yaş gruplarından kaynaklandığını belirten çalışmalar bulunmaktadır. Önder, Yalçın ve Göktaş (2013) "geleneksel cinsiyet rolleri”, "erkek cinsiyet rolleri” ve toplumsal cinsiyet toplam puanları açısından 21-22 yaşlarında olan öğrencilerin diğerlerine göre eşitlikçi tutum benimsedikleri sonucuna varılmıştır. Durgun-Köken ve Ulaş-Cambaz'ın (2019) çalışmasında yaşı 21 ve üzeri olanların, Seyitoğlu-Çelik, Güneş ve Gökçe (2016) yaşı daha genç olanların (17-19 yaş aralığında) daha eşitlikçi tutum içinde olduklarını belirtmiştir. Dinç ve Çalışkan (2016) ise öğrencilerin toplumsal cinsiyet rollerine ilişkin tutumlarının yaşa göre değişmediğini ifade etmektedir. Her ne kadar tutumun yaştan etkilenmediğini belirten çalışmaya rastlanılmış olsa da; bağımsız değişken olan "yaş" faktörü ögrencilerin toplumsal cinsiyet rollerine veya alt boyutlarına ilişkin tutumlarında etkili olduğu söylenebilir. Ayrıca daha eşitlikçi veya daha geleneksel tutum benimseyen öğrencilerin hangi yaş gruplarında olduğunun, yapılan çalışmalara göre değişiklik gösterdiği de görülmektedir.

Araştırmada 3. sınıf öğrencilerinin "eşitlikçi cinsiyet rolleri" ve "erkek cinsiyet rolleri" alt boyut ortalamaları 4. sınıfta okuyan öğrencilere daha yüksek bulunmuştur. Diğger bir deyişle, 3. sınıf öğrencilerinin erkeklerin cinsiyetlerinden dolayı kendilerinden beklenen rollere ilişkin 4. sınıftakilere göre daha eşitlikçi bir tutumu benimsedikleri söylenebilir. 4. sınıf öğrencilerinin alt boyutlardan "kadın cinsiyet rolleri" ve "geleneksel cinsiyet rolleri" ile toplumsal cinsiyet rollerine ilişkin tutum ortalamaları, 1. sınıf ve 3. sınıf öğrencilerinden daha düşük olarak bulunmuştur. $\mathrm{Bu}$ bulguya göre, 4.sınıf öğrencileri, 1.sınıf ve 3.sınıf öğrencilerine göre kadınların cinsiyetlerinden dolayı kendilerinden beklenen rollerine, geleneksel olarak toplumun kadın ve erkekten beklediği rollere ve toplumsal cinsiyet rollerine ilişkin daha geleneksel bir tutum içerisindedir. Önder, Yalçın ve Göktaş'ın (2013) çalışmasında 4.sınıf öğrencilerin erkek cinsiyet rolü alt boyut ortalaması, 1.sınıf öğrencilerine göre daha yüksek olduğu belirlenmiştir. Öğrencilerin okuduğu sınıf ile tutumları arasında fark olduğunu belirten Aydın ve Duğan (2018), öğrencilerin okuduğu sınıfın toplumsal cinsiyet rollerine ilişkin tutumlarını anlamlı düzeyde yordadığını; Başçı ve Giray ise (2016) öğrencilerin sınıfına göre TCRTÖ ortalamalarının farklılaştığını, 6. sınıf öğrencilerinin daha eşitlikçi tutuma sahip olduklarını belirtmiştir. Dinç ve Çalışkan (2016) ve Direk ve Irmak (2017) çalışmalarında ise öğrencilerin sınıfı ile tutumları arasında herhangi bir ilişkiye rastlanmamıştır. Çalışmamızın ve literatürdeki çalışmaların sonuçları birlikte değerlendirildiğinde, üniversite eğitiminin öğrencilere toplumsal cinsiyet rollerine daha eşitlikçi bir tutum kazandırma açısından yetersiz kaldığı söylenebilir. Her ne kadar bireyler içerisinde yaşadıkları toplumun beklenti, tutum ve inançlarından etkilenerek sosyalleşme sürecinde kendi tutum ve davranışlarını oluştursa da; sonradan kazanılan bu tutum ve inançların yavaş da olsa değişiminde eğitimin etkili olduğu düşünülmektedir.

Araştırma kapsamına alınan üniversite öğrencilerinin "evlilik cinsiyet rolleri” ve "erkek cinsiyet rollerine" ilişkin tutumlarının yaşamlarının çoğunluğunu geçirdiği yere göre farklılaştığı belirlenmiştir. Köy/kasabada "evlilik cinsiyet rolleri" alt boyut ortalaması, ilçe, il ve büyükşehirde yaşadığını belirten öğrencilere göre; "erkek cinsiyet rolleri” alt boyutu ortalaması, il ve büyükşehirde yaşamının çoğunluğunu geçiren öğrencilere göre daha düşük olarak bulunmuştur. Yaşamının çoğunluğunu köy/kasabada diğer bir ifade ile kırsal kesimde geçirdiğini belirten öğrencilerin kurulan evlilik birliğinde kadın ve erkeklerin rollerine ilişkin daha geleneksel bir yaklaşıma sahip olduğu, 
erkeklerden beklenen cinsiyet rollerine ise ataerkil düşüncenin izlerinin taşındığı tutum içinde oldukları söylenebilir. Nitekim yaşamın çoğunluğunun geçirildiği yerin, toplumsal cinsiyet rollerine ilişkin algılarda belirleyici bir etken olmadığı fakat tutumu etkilediği Çiçek ve Çopur (2018) tarafından da ifade edilmiştir. Yazıcı da (2016) yaşamının çoğunu büyükşehirde geçiren öğrencilerin “eşitlikçi cinsiyet rolü” alt boyut ortalamasının, yaşamının çoğunu köy/kasabada geçirenlere göre daha yüksek olduğu, yaşamının çoğunu büyükşehirde geçiren öğrencilerin daha eşitlikçi tutum içerisinde olduğu sonucuna varmıştır. Çalışmanın bulgularının aksine, kırsal kesimde yaşamının çoğunluğunu geçirdiğini belirten öğrencilerin daha eşitlikçi rol ve tutum içinde olduğu belirtilen (Durgun-Köken ve Ulaş-Cambaz, 2019) ve öğrencilerin en uzun süre yaşadıkları yere göre toplumsal cinsiyet rolü tutumlarında farklılık bulunmadığını ifade eden (Önder, Yalçın ve Göktaş, 2013) çalışmalara da rastlanılmıştır.

Öğrencilerin toplumsal cinsiyet rollerine ilişkin tutum ile "kadın cinsiyet rolleri”, "geleneksel cinsiyet rollerine" ilişkin tutumları öğrencilerin aile tiplerine göre de farklılaşmaktadır. Çekirdek ailede yaşadığını belirten öğrencilerin eşitlikçi bir tutum içinde oldukları söylenebilir. Çalışmanın bulgularına benzer şekilde Dinç ve Çalışkan (2016), Başçı ve Giray (2016), SeyitoğluÇelik, Güneş ve Gökçe (2016) ise çekirdek aile tipine sahip olan öğrencilerin diğer öğrencilerden daha eşitlikçi bir yaklaşım sergilediklerini belirtmiştir. Ergin, Bekar ve Acar-Aydemir (2019) ise ebeveynleri ayrı olanların daha eşitlikçi tutumlara sahip olduğunu ifade etmektedir.

\section{Sonuç ve Öneriler}

Üniversitelerin toplumların gelişimi ve dönüşümüne öncülük eden temel kurumlar olduğu göz önüne alındığında; üniversite öğrencilerinin toplumsal cinsiyet rollerine ilişkin tutumlarının incelenmesi büyük önem taşınmaktadır. $\mathrm{Bu}$ önem neticesinde yürütülen çalışmanın sonucunda, araştırmaya katılan öğrencilerin toplumsal cinsiyet rollerine ilişkin tutumlarının eşitlikçi yönde olduğu söylenebilir. Araştırma kapsamına alınan üniversite öğrencilerinin "eşitlikçi cinsiyet rolleri", "kadın cinsiyet rolleri", "evlilik cinsiyet rolleri", "geleneksel cinsiyet rolleri", "erkek cinsiyet rolleri"ne ilişkin tutumları öğrencilerin yaş gruplarına göre; toplumsal cinsiyet rollerine ilişkin tutumu ile "kadın cinsiyet rolleri", "geleneksel cinsiyet rollerine" ilişkin tutumları öğrencilerin aile tiplerine göre farklılaştığı görülmektedir.Sonuçlar göz önüne alındığında; üniversite öğrencilerinin toplumsal cinsiyet rollerine ilişkin eşitlikçi tutumu yaygınlaştırmaya ve artırmaya yönelik müdahale ve eğitim programları önerilebilir. Ayrıca bundan sonraki yapılacak araştırmalar için, geleneksel değerlere sahip olduğu belirlenen gençlerin bu görüşlerinin nedenleri ve görüşlerini etkileyen faktörler nitel yöntemlerle derinlemesine incelenebilir. Toplumsal cinsiyet rollerine yönelik tutumun öncelikle aile içerisinde edinildiği gerçeğinden yola çıkarak küçük yaşlardan itibaren çocukların toplumsal cinsiyet rollerine ilişkin kalıp yargılardan uzak, eşitlikçi bir yaklaşım sergilemesi noktasında en büyük rol model olan ebeveynlere büyük sorumluluklar düşmektedir. Ebeveynlere konuyla ilgili farkındalık sağlamak ve bilgi seviyelerini artırmak için ücretsiz hem anne hem de babaya hitap eden, zaman, mekân vb. konularda kolay ulaşılabiliranne-baba eğitimlerinin düzenlenmesinin önemli olduğu düşünülmektedir. $\mathrm{Bu}$ noktada, toplumsal cinsiyet eşitliğinin yaygınlaştırılması amacıyla ebeveynlere hizmet götüren, bu konularda çalışma yapan ve yapmayı hedefleyen tüm kamu ve özel kurum, kuruluşları, sivil toplum örgütleri, yerel yönetimler yer alabilir.

Üniversite öğrencilerine konuyla ilgili bilinç ve farkındalık oluşturmak amacıyla seminerler verilmesi, konferanslar düzenlenmesi, ayrıca toplumsal cinsiyet eşitliğini konu olan derslerin müfredat programlarına eklenmesi önerilebilir. 


\section{Kaynakça}

Agacinski, S. (1998). Cinsiyetler siyaseti. (Çeviren: İsmail Yergüz). Dost Kitabevi.

Akın, A., \& Demirel, S. (2003). Toplumsal cinsiyet kavramı ve sağlığa etkileri. Cumhuriyet Üniversitesi Tıp Fakültesi Dergisi, Halk Sağlı̆̆ı Özel Eki, 25(4),73-83.

Alabaş, R., Akyüz, H. İ., \& Kamer, S. T. (2019). Üniversite öğrencilerinin toplumsal cinsiyet algılarının belirlenmesi. Mustafa Kemal Üniversitesi Sosyal Bilimler Enstitüsü Dergisi, $16(44), 429-448$.

Alan-Dikmen, H., \& Marakoğlu, K. (2019). Hemşirelik öğrencilerinin toplumsal cinsiyet rolleri ile kadına yönelik şiddete ilişkin tutumlarının incelenmesi. Genel Tip Dergisi, 29(2), 73-79.

Alpar, R. (2011). Uygulamalı çok değişkenli istatistiksel yöntemler. Detay Yayıncılık.

Aydın, B. O., \& Duğan, Ö. (2018). Halkla ilişkiler lisans öğrencilerinin toplumsal cinsiyet rollerine yönelik Tutumları. Necmettin Erbakan Üniversitesi Güzel Sanatlar Fakültesi Dergisi, 1(1), 88-102.

Başç1, B., \& Giray, S. (2016). Üniversite öğrencilerinin toplumsal cinsiyet rollerine ilişkin tutumlarının çok değişkenli istatistiksel tekniklerle analizi. Journal of Life Economics, 3(4), 117-142. https://doi.org/10.15637/jlecon.160

Çevik-Büyükşahin, G. (2017). Üniversite öğrencilerinin toplumsal cinsiyet rolleri ve çatışma çözme stillerinin incelenmesi. Mersin Üniversitesi Eğitim Fakültesi Dergisi,13(3), 1017-1034. https://doi.org/10.17860/mersinefd.320021

Çiçek, B., \& Çopur, Z. (2018). Bireylerin kadınların çalışmasına ve toplumsal cinsiyet rollerine ilişkin tutumları. International Journal of Eurasian Education and Culture, 4, 1-21.

Daşl1, Y. (2019). Öğrencilerin toplumsal cinsiyet rollerine ilişkin tutumların belirlenmesi üzerine bir alan araştırması. YYÜ Ĕ̈itim Fakültesi Dergisi, 16(1), 364-385.

Dinç, A., \& Çalışkan, C. (2016). Üniversite öğrencilerinin toplumsal cinsiyet rollerine ilişkin bakış açıları. Journal of Human Sciences, 13(3), 3671-3683.

Direk, N., \& Irmak, B. (2017). Dokuz Eylül Üniversitesi Tıp Fakültesi öğrencilerinde toplumsal cinsiyet rollerine yönelik tutumlar. Dokuz Eylül Üniversitesi Tip Fakültesi Dergisi, 31(3), 121-128.

Durgun-Köken, S., \& Ulaş-Cambaz, N. (2019). Ebelik/hemşirelik öğrencilerinin toplumsal cinsiyet rollerine ilişkin tutumlarının belirlenmesi. Medical Sciences (NWSAMS), 14(2), 93-103.

Ergin, A., Bekar, T., \& Acar-Aydemir, G. (2019.) Tıp fakültesi öğrencilerinin toplumsal cinsiyet rollerine yönelik tutumları ve etkileyen faktörler. Fırat Tıp Dergisi, 24(3), 122-128.

Ertürk, Y. (1996). Alternatif kalkınma stratejileri, toplumsal cinsiyet, kadın ve eşitlik. Odtü Gelişme Dergisi, 23(3), 341-356. https://doi.org/10.17233/sosyoekonomi.2018.04.13

Huston, A.C. (1985). The development of sex typing: Themes from recent research. Development Review,5, 1-17. https://doi.org/10.1016/0273-2297(85)90028-0

Görgün-Baran, A.(2012). Davranış bilimleri. Siyasal Kitabevi.

Illich, I. (1996). Gender. (Çeviren: Ahmet Fethi). Ayraç Yayınevi.

Kammayer, K. C. W. (1987). Marriage \& family. A foundation for personal decision. Allyn and Bacon. 
Kimmel, M.S. (1987). Rethinking masculinity new directions in research. Chancing man new directions in research on man and masculinity. Sage Publication.

Oakley, A. (1972). Sex, gender and society. Temple Smith.

Önder, Ö. R., Yalçın, A.S., \& Göktaş, B. (2013). Sağlı kurumları yöneticiliği bölümü öğrencilerinin toplumsal cinsiyet rollerine ilişkin tutumları. Ankara Sağlık Bilimleri Dergisi, 2(1-2-3), 5578. https://doi.org/10.1501/Asbd_0000000042

Öngen, B., \& Aytaç, S. (2013). Üniversite öğrencilerinin toplumsal cinsiyet rollerine ilişkin tutumları ve yaşam değerleri ilişkisi. Sosyoloji Konferansları, 48, 1-18.

Savc1, İ. (1999). Toplumsal cinsiyet ve teknoloji. Ankara Üniversitesi Siyasal Bilgiler Fakültesi Dergisi, 54(1), 123-142. https://doi.org/10.1501/SBFder_0000001939

Seyitoğlu-Çelik, D., Güneş, G., \& Gökçe, A. (2016). İnönü Üniversitesi Tıp Fakültesi öğrencilerinin toplumsal cinsiyet rollerine ilişkin tutumlarının belirlenmesi. Medicine Science, 5(1),102116.

Staggenborg, S. (1998). Gender, family and social movements. Pine Forge Press.

Uluocak, Ş., Gökulu G., Bilir, O., E. Karacık, N., \& Özbay, D. (2014). Toplumsal cinsiyet eşitsizliği ve kadına yönelik şiddet. Paradigma Akademi Yayınları.

Şafak, B. (2003). Antropoloji sözlüğ̈̈. K. Emiroğlu ve S. Aydın (Ed). Bilim ve Sanat Yayınları.

T.C. Başbakanlık Kadının Statüsü Genel Müdürlüğü (2008). Toplumsal Cinsiyet Eşitliği Ulusal Eylem Planı 2008-2013, Ankara, http://www.kadininstatusu.gov.tr. Erişim Tarihi: 08.03.2020.

Vatandaş, C. (2007). Toplumsal cinsiyet ve cinsiyet rollerinin algılanışı. Sosyoloji Konferanslarl, $35,29-56$.

West, C., \& Zimmerman, D. H. (1987). Doing gender. Gender \& Society, 1(2),125-151.

Yazıcı, T. (2016). Müzik öğretmeni adaylarının toplumsal cinsiyet rollerine ilişkin tutumları. Akademik Baklş Dergisi, 54, 833-852. https://doi.org/10.18039/ajesi.577713 